\title{
Perceived Effects of Rural-Urban Interactions on Sustainable Agricultural Development in Nigeria
}

\author{
Olaniyan Oluwafolakemi Ayo \\ Department of Vocational and Technical Education, Adekunle Ajasin University, Akungba-Akoko, Ondo State, Nigeria
}

Received April 8, 2020 ; Revised June 4, 2020; Accepted June 16, 2020

Copyright $(\mathcal{C} 2020$ by authors, all rights reserved. Authors agree that this article remains permanently open access under the terms of the Creative Commons Attribution License 4.0 International License

\begin{abstract}
The fact that a correlation exists between agricultural production and poverty alleviation efforts in Sub-Saharan African countries is not an understatement. This is based on the fact that majority of people in the developing countries of Africa including Nigeria live in the rural areas and primarily engage in agriculture as their source of livelihood. However, most rural areas in Nigeria still battle with food insecurity, malnutrition and poor economy. This study therefore explores the perceived effects of rural-urban interactions on sustainable agricultural development in Nigeria. The population of the study consisted of all the rural dwellers in the study area from which 300 respondents were selected through multi-stage sampling procedure. The instrument of data collection was a well-structured, validated and reliable interview schedule. Five research objectives and two hypotheses were developed and tested in the study. Findings from the study revealed that the community-based agricultural projects provided based on rural-urban interactions were provision of improved varieties of seeds to farmers, provision of improved breeds of animals, provision of farm tools and provision of loans to farmers for buying farm inputs $(\overline{\mathrm{x}}=0.367,0.273,0.256$ and 0.236 ) respectively. Also, the motivational factors for rural-urban interactions had significant effect on the respondents' participation in the community-based agricultural projects $\left(\mathcal{X}^{2}=1.595 \mathrm{p}<0.05\right)$. It was therefore concluded that rural-urban interactions should be factored into community development activities to promote sustainable agricultural development.
\end{abstract}

Keywords Effects, Rural-Urban, Interactions, Sustainable, Development

\section{Introduction}

Agricultural development is the systematic attempt of re-organising and mobilising the rural masses in order to improve agricultural production and rural dwellers' capacity to cope effectively with global changes and demands. This can be achieved through the provision of social, economic and infrastructural facilities that can stimulate agricultural production, alleviate rural poverty and enhance the quality of life of rural dwellers (Ogunleye-Adetona, 2013). This is rooted in the fact that rural development is a panacea for replacing rural poverty with prosperity in the developing countries of the world as a large proportion of her populace are domiciled in rural areas and primarily engaged in agriculture as their source of livelihood (Enyi, 2014).

The interdependence between rural and urban areas is increasing rural growth (especially within food systems), underpins the sustainability of urban areas and this growth in urban sectors also provides opportunities to raise rural incomes (IFAD, 2015). However, divergent views and thoughts trail the contributions of urban communities to agricultural development and rural transformation. Some are of the opinion that urban communities have negatively affected the development of the rural areas in that the urban centers are being developed at the expense of the rural areas. Toyobo and Muili (2008) in Nigeria commented that the pressure on community infrastructures have been accentuated by the parallel modernization of urban economies and the marginalization of rural economy. Conversely, Tacoli and McGranahan (2014) asserted that the network of small, medium sized and large urban centers is vocationally efficient in that urban areas allow cluster of services, facilities and infrastructures that cannot be economically located in small villages to serve a widely dispersed population in supplying both agricultural and non-agricultural services in the sense that it is from the urban areas that innovation trickles down to the rural populace. The thrust of this study was to determine the perceived effects of rural -urban interactions on sustainable agricultural development in Nigeria by addressing the following specific objectives: i. ascertain the 
socio-economic characteristics of the respondents; ii. identify the factors that motivate the respondents towards rural-urban interactions; iii. indicate forms of rural-urban interactions iv. determine the rural dwellers' level of participation in community-based agricultural projects; and v. determine the respondents' perception of the effects of rural-urban interactions on their participation in community-based agricultural projects. The study tested two null hypotheses as:

$\mathrm{Ho}_{1}$ : there is no significant relationship between the selected socio-economic characteristics of the respondents and their participation in community-based agricultural Projects; and

$\mathrm{Ho}_{2}$ : there is no significant relationship between the respondents' motivational factors for rural- urban interactions and their participation in community-based agricultural projects.

\section{Review of Literature}

It is not an understatement that Agriculture is the main stay of Nigerian economy as evidenced from the fact that majority $(70-80 \%)$ of her labor force engage in farming. According to Aromolaran, Alarima, Abiona, Adekola and Amole (2018), development is a gradual process which brings about changes in growth, advancement and transformation in the physical, environmental, social and economic aspects of human life. Meanwhile, Lewis (1954) had earlier submitted that economic growth is a function of agricultural development and industrialization which involves the reallocation of resources from a backward low productivity agricultural sector to modern industrial sector with higher productivity and increasing returns.

Rural-urban linkages on the other hand can be defined as the structural, social, economic, cultural, and political relationship between individuals and groups in the rural areas and those in the urban environment. According to Trager (2000) a complex form of interrelationship exists between the rural and urban areas especially in the form of migration in which the migrants are described as multilocals participating in social activities and organizations across these two areas. In the same vein, Lindile (2013) asserted that the existence of a web of inter-relationships and networks that link both urban and rural spaces clouded the distinction between rural and urban spaces. For instance, labour migration, flows of information and services such as education and healthcare, enable people to keep one foot in the rural economy and the other in the urban economy. Most rural areas depend on urban areas for university education, credit, agriculture-led services such as farm equipment and advice, hospitals and government services while urban areas depend on rural areas for water resources, food production, and waste disposal. Similarly, urban waste can be used as a source of organic matter or as source of nutrients for agriculture which can help rural farmers to restore degraded soils and turn unproductive land into valuable agricultural land. Rural -urban interactions are categorized into spatial and sectoral interactions. Spatial interaction deals with the movement of people or linkages across space, flow of cash, flow of commodities and environmental resources, flow of information and technological innovations. Spatial linkages according to Mushi (2003) include flow of agricultural commodities from rural to urban markets, and in the opposite direction flow of manufactured and imported goods from urban areas to rural settlements. They also include flow of people commuting between rural and urban settlements either daily, or seasonally to urban-based services and administrative centres. Flows of information on markets and price fluctuations between urban and rural areas are also other types of rural-urban linkages. Financial flows include remittances from migrants to relatives and communities. The flow of goods and services involve the transfer of income, people and capital from one place to another among households dispersed in the settlements. The linkages between rural and urban areas represent the daily transactions that take place between farmers and traders, producers of goods and services in urban areas and consumers.

Therefore, the myriads of exchanges of goods and services that take place in daily transactions cumulatively bring about multiplier effects in the long run. These effects contribute to enhanced livelihoods in both rural and urban areas. Spatial linkages could be advantageous considering the flows of people and goods from rural to urban and back, and the importance of multi-spatial households on rural development (Tacoli, 2004). Sectoral interaction on the other hand refers to occupations and activities typified of one locality but found in both places. For instance, rural activities such as rural non-farm employment (manufacturing and some other urban services taking place in rural areas) and activities often classified as rural such as urban agriculture taking place in urban areas. It also includes forward and backward linkages between agriculture and manufacturing services, for instance, production of agricultural inputs in urban areas such as fertilizers and farm implements, and existence of processing industries in rural areas. The increasing emergence of sectoral interaction as observed in the rural communities of Nigeria is what Bryceson (1999) described as de-agrarianisation, occupational adjustment, social identification, income earning diversification of rural dwellers away from strictly peasant modes of livelihood to non-farm activities but not necessarily abandoning farming. According to Iliya (1999), these non-farm activities are often mean for small households to accumulate capital. These according to Akkoyunlu (2013) affirmed the fact that many people in rural areas engage in urban activities such as manufacturing and service provision while many people in urban areas also engage in agricultural production, either for household consumption or for sale or 
both. Rural and urban economies therefore are interdependent, intertwined and complementary.

Moreover, Olariu (2012) identified some possible influences that urban areas could have on rural areas as: higher rural income due to urban demand for high value crops and food stuffs; remittances from urban based family members which may be important for investment in agricultural production as well as rural consumption; non-farm employment or rural industrialization; most rural producers depend on urban centers for access to markets, agricultural services, credit and farm equipment and supplies, and access to public and private sector services. Therefore, positive rural-urban linkage may contribute to sustainable agricultural development by stimulating community members' participation in agricultural projects.

\section{Methodology}

\section{Area of Study}

The study was carried out in Edo and Ondo States, Nigeria. Edo State which is in the South-South geopolitical zone of Nigeria was created on August 27, 1991 by the administration of President Badamosi Babangida. It lies approximately between longitude $6^{0} 04^{1} \mathrm{E}$ and $6^{0} 43^{1} \mathrm{E}$ of the Greenwich Meridian and latitude $5^{0} 44^{1} \mathrm{~N}$ and $7^{0} 34^{1} \mathrm{~N}$ of the equator. The climate of Edo State is typically tropical with two major seasons: the wet and the dry seasons and this favours dominant occupation of the people, which is agriculture. The main ethnic groups in Edo State are Edos, Afemais, Esans, Owans and Akoko Edo. Meanwhile, Ondo State was founded on February 3, 1976 from the former Western State as one of the six states that make up the South West geopolitical zone of Nigeria and covers an area of approximately $15,195.2$ square kilometers. It lies at latitude $7^{\circ} 10^{\prime}$ North and longitude $5^{\circ} 05^{\prime}$ East and has a population of 3,460,877 and a population density of 218 people per square kilometer (NPC, 2006). It accounts for $2.5 \%$ of Nigeria's total population. Ondo State falls within the tropical humid climate that is characterized by wet and dry season. Agriculture is the traditional occupation of the people with a significant percentage of the state's labor force engaging in Cocoa farming.

\section{Research Design}

The study adopted the descriptive research design of the survey type.

\section{Population of the Study}

The population of this study comprised of rural dwellers that have in one way or the other interacted with urban areas and participated in Community-based Agricultural Projects within their communities in Edo and Ondo State, Nigeria.

\section{Sample Size}

A total sample size of 300 rural dwellers respondents were selected across the 30 sampled villages in the two states.

\section{Sampling Strategy}

A multi-stage sampling technique was used to select respondents for this study. At the first stage, three local government areas were purposively selected from each of the two states based on their classification as rural, existence of rural-urban interactions and the presence of Community-based Agricultural Projects in the area(Akoko South West, Odigbo, Ondo East, Ovia North East, Ovia South West and Ikpoba- Okha were selected). This gave a total of six local government areas in all.

At the second stage, five villages were randomly selected from each of the local government areas using the list of the available community-based agricultural projects and their location in the selected villages as the sampling frame. Thus, a total of 30 villages were selected. The villages selected across the two states were: Oka-odo; Etioro; Oba; Supare; Ilale; Ajue; Ominitin, Lasia; Igburowo; Asejire; Fagbo; Igbo-oja; Owena; Bolorunduro; Igba; Egbetta; Utese; Iguomo; Uhen; Ugbuwe; Iguobazuwa; Usen; Ofunwegbe;Iguoriakhi; Udo; Ukiri; Kagba; Emelu; Idogbo and Egba.

At the last stage, ten rural dwellers were purposively selected and interviewed from each of the villages based on their interactions with the urban areas and participation in community-based agricultural projects within their villages.

\section{Methods of Data Collection}

The data for this study were collected through primary and secondary sources. Primary data were collected from the respondents through the use of well-structured, validated and pre-tested interview schedule. Secondary source of information was gathered from existing literature, publications in journals and proceedings, internets, relevant reports and other sources relevant to the study.

\section{Measurement of Variables}

Two sets of variables were measured in the study. The independent variables comprised of selected socio-economic characteristics of the respondents, motivational factors for rural-urban interactions, forms of rural-urban interactions and the respondents' perception of the effects of rural-urban interactions on their participation in agricultural projects. The dependent variable is the respondents' level of participation in these agricultural projects. 


\section{Data Analysis}

The data collected were analysed on SPSS version 22 through both descriptive and inferential statistics. Descriptive statistics used include: frequency distribution, percentages and mean while the inferential statistics utilized was Chi-square.

\section{Presentations}

Data were presented in Tables using Figures.

\section{Results and Discussions}

Results in Table 1 denote that $72.4 \%$ of the respondents were within the age bracket of 26 and 55 years while $27.7 \%$ of the respondents were above 55 years of age. The mean age of the respondents was 46 years. These observations suggested that majority of the respondents were matured and active as they are at their productive age. This implies that productive and active members of the rural community should be given the opportunity to participate effectively in community development projects to ensure sustainable rural development (Okunlola and Adesida, 2015). 57.0\% of the respondents were male, while $43.0 \%$ were female. This shows that women's participation in rural-urban interactions and community development projects is on the increase. According to Tacoli (2014) this may be necessitated by their feeling of being responsible for the well-being of the members of their households, especially in local areas where women's employment and independence opportunity are limited. It was also observed that $65.0 \%$ of the respondents were Christians, $29.7 \%$ were Muslims, while $5.3 \%$ practiced traditional religion. This is an indication that communalism can be promoted through religious diversity. The implication is that the various religious bodies can be used as channels of disseminating information on community development projects as well as encouraging members' participation since no religious group has anything against participation in Community Development Projects. Only 5.7\% of the respondents had no formal education. This suggests that the literacy level of the respondents was very high and this can facilitate their understanding of the relevance of the projects to their livelihood and access to information on community development projects as previous study had shown that a significant relationship exists between literacy level and access to information (Adisa, Akinbile and Oladoja, 2004).

This finding supported the assertion of Okunlola and Adesida (2015) that basic and advanced education should be experienced at different levels to foster proper appreciation of community efforts. Correspondingly, Fhika (2015) posited that the more educated the people are, the higher their level of participation in community development projects due to the fact that many of them have gainful employment and disposable income that can ensure financial contribution to community development. This could be responsible for the high number and level of participation recorded for educational facilities in the study. The implication is that every member of the community should be given free access to qualitative education. It is evident from Table 1 that majority of the respondents $(67.0 \%)$ were married while $16.0 \%, 8.3 \%$ and $8.7 \%$ were single, divorced and widowed respectively. This points to the fact that marriage and family-hood are well appreciated in rural settings as individuals that are married are regarded as responsible. This could also promote the availability of more family labor on the farm and participation in community development projects. Moreover, $49.7 \%$ of the respondents had household size of between 4 and $7,32.3 \%$ had between 8 and 11 household size, 15.3\% had the household size of between 12 and 15 , while just $2.7 \%$ of the respondents had household size of 16 and above. The mean household size is 7 . This distribution of the respondents based on their household size corroborates the submission of Oyesola and Oladeji (2006) that moderate household size is advantageous to participation in community development in the sense that the heads of the household are not saddled with much financial burden in taking care of the family members who can impede participation in community-based projects. This implies that moderate household size should be encouraged among rural dwellers to reduce pressure on family sustenance and allow for more commitment to development. The primary occupations of the respondents include: farming (32.3\%), trading $(26.3 \%)$, civil service and artisan (18.7\%)) respectively. A minor (4\%) proportion of the respondents were engaged in other occupations such as transportation, hair dressing, blacksmithing and patent medicine. This is an indication that the rural area is undergoing rapid livelihood diversification. The distribution of the respondents based on their average monthly income showed that $40.7 \%$ of the respondents earned monthly income of between $\$ 30,000$ and $\$ 50,999$. Only $30.3 \%$ of the respondents realized between $\$ 51,000$ and $\$ 70.999$ per month, while just $29 \%$ of the respondents made monthly income of between 71,000 and $\$ 111,999$. This finding further accentuates the poverty status of the rural dwellers. It also underscores the Human Development Report (HDR) (2018) which stated that Nigeria is one of the poorest among the poor countries of the world with the rank of 157 out of 189 and Human Development Index (HDI) value of 0.532and a life expectancy of 54 years for female, 53 years for male; $44 \%$ literacy rate and $70 \%$ rural population living on less than 2 dollars per day and lacking adequate access to clean and safe water, education and health care facilities, electricity, housing and good road networks. The implication is that all the stakeholders involved in rural development should look inward and conduct periodic review of all past rural development programmer in Nigeria (Ladele and Olaniyan, 2015). Majority (90\%) of the respondents belong to one 
community development group or the other, while just $(10 \%)$ of the respondents did not join any community development group. This is an indication that information on the community development projects can easily be circulated to members. This is in line with the postulation of Mwaura \& Ngugi (2014) and Adeleke and Ashimolowo
(2015) that membership of community development groups promotes informed decision and profitable involvement in community development projects. This therefore suggests that the potentials inherent in membership of community development groups should be harnessed for sustainable rural development.

Table 1. Percentage distribution of the rural dwellers according to their socio-economic characteristics

\begin{tabular}{|c|c|c|c|}
\hline \multicolumn{2}{|c|}{ Socio economic characteristics } & \multirow{2}{*}{$\begin{array}{c}\text { Frequency } \\
56\end{array}$} & \multirow{2}{*}{$\begin{array}{c}\text { Percentage } \\
18.7\end{array}$} \\
\hline & $26-35$ & & \\
\hline A & $36-45$ & 66 & 22.0 \\
\hline Age(Y ears) & $46-55$ & 95 & 31.7 \\
\hline \multirow{3}{*}{ Mean age $=46$ years } & $56-65$ & 59 & 19.6 \\
\hline & $66-75$ & 22 & 7.3 \\
\hline & Above 75 & 2 & 0.7 \\
\hline \multirow{3}{*}{ Sex } & Male & 171 & 57.0 \\
\hline & Female & 129 & 43.0 \\
\hline & Christianity & 195 & 65.0 \\
\hline \multirow{2}{*}{ Religion } & Islam & 89 & 29.7 \\
\hline & African Traditional Religion & 16 & 5.3 \\
\hline \multirow{8}{*}{ Educational Attainment } & No Formal Education & 17 & 5.7 \\
\hline & Attended Primary School & 22 & 7.3 \\
\hline & Completed Primary School & 13 & 4.3 \\
\hline & Adult Literacy & 40 & 13.3 \\
\hline & Attended Secondary School & 41 & 13.7 \\
\hline & Completed Secondary School & 48 & 16.0 \\
\hline & Attended Tertiary School & 60 & 20.0 \\
\hline & Completed Tertiary School & 59 & 19.7 \\
\hline \multirow{4}{*}{ Marital Status } & Single & 48 & 16.0 \\
\hline & Married & 201 & 67.0 \\
\hline & Divorced & 25 & 8.3 \\
\hline & Widowed & 26 & 8.7 \\
\hline \multirow{4}{*}{$\begin{array}{l}\text { Household size (Number) } \\
\text { Mean=7 }\end{array}$} & $4-7$ & 149 & 49.7 \\
\hline & $8-11$ & 97 & 32.3 \\
\hline & $12-15$ & 46 & 15.3 \\
\hline & $16 \&$ above & 8 & 2.7 \\
\hline \multirow{8}{*}{ Primary Occupation } & Farming & 97 & 32.3 \\
\hline & Trading & 79 & 26.3 \\
\hline & Artisan & 56 & 18.7 \\
\hline & Civil Service & 56 & 18.7 \\
\hline & Transportation & 3 & 1.0 \\
\hline & Hair dressing & 5 & 1.7 \\
\hline & Blacksmithing & 3 & 1.0 \\
\hline & Patient medicine & 1 & 0.3 \\
\hline \multirow{5}{*}{$\begin{array}{l}\text { Average monthly income } \\
\text { (Naira) }\end{array}$} & $30,000-50,999$ & 122 & 40.7 \\
\hline & $51,000-70,999$ & 91 & 30.3 \\
\hline & $71,000-90,999$ & 39 & 13.0 \\
\hline & $91,000-110,999$ & 28 & 9.3 \\
\hline & $111.000 \&$ above & 20 & 6.7 \\
\hline \multirow{2}{*}{ Membership of CBPG } & Yes & 270 & 90.0 \\
\hline & No & 30 & 10.0 \\
\hline
\end{tabular}

Source: Field survey, 2019 
Table 2. Percentage distribution of the respondents based on the motivational factors for rural- urban interactions

\begin{tabular}{|c|c|c|}
\hline Motivational factors for rural-urban interaction (out-flow to urban) & Frequency & Percentage \\
\hline I interact with urban areas because of the possibility of getting innovations in agriculture & 216 & 72.0 \\
\hline I belief that urban areas will offer me access to great economic transaction & 209 & 69.7 \\
\hline There are better opportunities for training and skill acquisition in the urban centres than rural areas & 220 & 73.7 \\
\hline Rural urban interaction is an opportunity for me to visit my families and relations in the cities & 241 & 80.3 \\
\hline It serves as fora for meeting people in agricultural societies and groups. & 179 & 59.7 \\
\hline It could be a germane avenue for the exchange of environmental goods and amenities & 145 & 48.3 \\
\hline I expect that the cities will be stocked with improved infrastructures and public utilities than rural areas & 233 & 77.7 \\
\hline $\begin{array}{l}\text { In this era of technology, I am of the opinion that interaction with urban areas will expose me and my } \\
\text { children to modern technologies and idea for livelihood and community development }\end{array}$ & 237 & 79.0 \\
\hline \multicolumn{3}{|l|}{ Motivational factors for rural-urban interaction(in-flow to rural) } \\
\hline As for me rural area is peaceful unlike the experience in the urban area due to congestion & 270 & 90.0 \\
\hline $\begin{array}{l}\text { As an entrepreneur I see rural area as an avenue for me to market my products as well as contribute my } \\
\text { own quota to community development as there are less competitors }\end{array}$ & 164 & 54.7 \\
\hline $\begin{array}{l}\text { Living with one's community members could foster love, security and sense of belonging among the } \\
\text { people }\end{array}$ & 239 & 79.7 \\
\hline $\begin{array}{l}\text { Back at home I could use the knowledge gained in the urban area to reinforce my people for agricultural } \\
\text { development }\end{array}$ & 211 & 70.3 \\
\hline I would enjoy better access to irreplaceable rural goods and services back home & 188 & 62.7 \\
\hline It could serve as an avenue for me to teach my children our culture and their history & 216 & 72.0 \\
\hline $\begin{array}{l}\text { As a philanthropist my returning home could attract development to my village due to the donations of my } \\
\text { friends and community members in the cities }\end{array}$ & 120 & 40.0 \\
\hline There is the tendency of saving more money for farming in rural area as the cost of living is low & 257 & 85.7 \\
\hline
\end{tabular}

Source: Field survey, 2019

\section{Factors that Motivate the Respondents towards Rural-urban Interactions}

Results on Table 2 indicate that the four most important factors that motivated rural-urban interactions among the respondents were: the peaceful nature of the rural area, unlike the experience in the urban area due to congestion $(90 \%)$, tendency of saving more money for community development in rural area because the cost of living is low $(85.7 \%)$, rural-urban interaction is an opportunity to visit family and relations in the cities(80.3) and living with family members which could foster love, security and sense of belonging among the people (79.7\%). This suggests that the respondents enjoyed mutual benefits from rural-urban interactions as they are motivated to interact with urban areas because of certain reasons to fulfil their needs, they also see reasons to return home. This corroborates the findings of Aliabakar, Mirnajaf and Hamidian ( 2014) that the concentration of population, facilities, services and various functions in the centres or metropolitans has motivated the rural-urban interactions of the population living in the outskirts of cities to fulfill their needs, thus facilitating the development of the villages with proximity to the cities. This is an indication that the simultaneous growth of urban-type income generating activities from rural-urban interactions has succeeded in reducing the rate of migration to the cities (Okali, Okpara and Olawoye, 2001).

\section{Forms of Rural-urban Interactions (Spatial Out-flow and In-flow of People, Commodity and Information)}

It is evident from Table $3 \mathrm{~A}$ that majority of the respondents (99.3\%) engaged in spatial (out-flow) ruralurban interactions while $91.7 \%$ are involved in spatial in-flow rural-urban interactions. Bah,Cisse, Diyamett, Diallo, Lerise, Okali, Okpara, Olawoye and Tacoli (2003) in a related study had earlier submitted that rural-urban 
interactions are considered essential in South Eastern Nigeria as young men and women who do not interact with towns or cities are labelled idle and tagged objects of ridicule. Those who interact with urban areas send money to their family and friends in the villages and contribute to the success of their villages especially during festive period. This was observed in Mali, Nigeria and Tanzania where $50 \%$ to $80 \%$ of households have at least one migrant member and remittances not only contribute to households' consumption, but also are re-invested in local production activities. The implication is that the close and dynamic relationship between rural and urban areas if properly channelled could foster participation in community-based projects.

\section{Forms of Rural-urban Interactions (Sectoral Form of Rural-urban Interactions)}

As shown in Table 3B, about $53.7 \%$ of the respondents engage in rural farming as a sectoral source of livelihood while other sectoral activities include petty trading $(36.3 \%)$, urban agriculture (35\%), building construction $(30.7 \%)$ and civil service (28\%). Lack of viable employment in the city may prompt people to drift to rural areas to practice rural farming. The farming source of livelihood indicated by the respondents were rural farming and urban agriculture; the trading source of livelihood includes petty trading, patent medicine store and provision store, production source of livelihood includes brewing of local gin, rural industry and manufacturing; while the artisan category includes furniture making, barbing salon, mechanic, block making, hair dressing, blacksmithing, fashion designing, building construction and arts craft. This shows that some level of occupational adjustment, variations or seasonality is been experienced in the study area. This corroborates the earlier findings of Mushi (2003) and Akkoyunlu (2013) that many poor urban dwellers rely on seasonal employment in agriculture or rural development projects or on collecting or purchasing resources from nearby rural areas for their own use and for sale. Similarly, the increase $(35 \%)$ in the level of urban farming is in line with the submission of Tacoli (2004) that there is a growth in urban agriculture since the late 1970s as a response to escalating poverty and rising food prices or shortages which were exacerbated by the implementation of the structural adjustment policies in the 1980s. Studies have shown that high and middle income households constitute a significant and growing proportion of urban farmers who often engage in urban farming for commercial purpose. This further confirms the position of Oyesola and Oladeji (2006) that there is a process of occupational adjustment, income earning, social identification and spatial relocation ongoing in both rural and urban centers. This could promote rural transformation through concerted effort in community-based projects.

Table 3A. Distribution of the respondents based on the forms of rural-urban interactions (Spatial)

\begin{tabular}{|c|c|c|c|c|c|c|c|c|c|c|}
\hline & \multicolumn{2}{|c|}{ Flow of people } & \multirow{2}{*}{\multicolumn{2}{|c|}{ Daily }} & \multicolumn{4}{|c|}{ Frequency of flow } & \multirow[b]{2}{*}{ Monthly } & \multirow[b]{2}{*}{ Every 6 months } \\
\hline & Yes & No & & & Every othe & r day & Weekly & Fortnightly & & \\
\hline Out flow & 298(99.3) & $2(0.7)$ & $113(3$ & 7.7) & $35(11.7$ & & $32(10.7)$ & $16(5.3)$ & $57(19.0)$ & $47(15.7)$ \\
\hline \multirow[t]{3}{*}{ In flow } & $275(91.7)$ & $25(8.3)$ & $98(35$ & $5.6)$ & $34(12.4$ & & $32(11.6)$ & $13(4.7)$ & $57(20.7)$ & $41(14.9)$ \\
\hline & \multicolumn{2}{|c|}{ Flow of commodity } & \multicolumn{8}{|c|}{ Frequency of flow } \\
\hline & Yes & No & Daily & Every & other day & Wee & & Fortnightly & Monthly & Every 6 month \\
\hline Out- flow & $236(78.7)$ & $64(21.3)$ & $9(3.8)$ & & (28.8) & $55(2$ & (3.3) & $41(17.4)$ & $38(16.1)$ & $5(10.6)$ \\
\hline \multirow[t]{3}{*}{ In- flow } & $186(62.0)$ & $114(38.0)$ & $4(2.2)$ & & $(10.8)$ & $53(2$ & $8.5)$ & $47(25.3)$ & $32(17.2)$ & $30(16.1)$ \\
\hline & \multicolumn{2}{|c|}{ Flow of information } & \multicolumn{8}{|c|}{ Sources of flow of information } \\
\hline & Yes & No & \multicolumn{2}{|c|}{ Print media } & \multicolumn{3}{|c|}{ Electronic media } & Social media & \multicolumn{2}{|c|}{ Oral media } \\
\hline Out-flow & 297(99.0) & $3(1.0)$ & \multicolumn{2}{|c|}{$41(13.8)$} & \multicolumn{3}{|c|}{$103(34.7)$} & $37(12.5)$ & \multicolumn{2}{|c|}{$116(38.7)$} \\
\hline In -flow & $290(96.7)$ & $10(3.3)$ & \multicolumn{2}{|c|}{$7(2.4)$} & \multicolumn{3}{|c|}{$129(44.5)$} & $30(10.3)$ & \multicolumn{2}{|c|}{$124(42.8)$} \\
\hline
\end{tabular}

Source: Field survey, 2019 
Table 3B. Distribution of the respondents based on the Sectoral form of rural-urban interactions engaged in

\begin{tabular}{ccc}
\hline Sectoral Activities & Yes* & No* $^{*}$ \\
\hline Rural farming & $161(53.7)$ & $139(46.3)$ \\
Petty Trading & $109(36.3)$ & $191(63.7)$ \\
Urban agriculture & $105(35.0)$ & $195(65.0)$ \\
Building Construction & $92(30.7)$ & $208(69.3)$ \\
Civil service & $84(28.0)$ & $264(72.0)$ \\
Transportation & $62(20.7)$ & $238(79.3)$ \\
Priest & $61(20.3)$ & $239(79.7)$ \\
Artisan & $49(16.3)$ & $251(83.7)$ \\
Provision store & $33(11.0)$ & $267(89.0)$ \\
Herbalist & $25(8.0)$ & $275(91.7)$ \\
Brewing of local gin & $32(10.7)$ & $268(89.3)$ \\
Rural industry and manufacturing & $20(6.7)$ & $280(93.0)$ \\
Patient medicine store & $18(6.0)$ & $282(94.0)$ \\
\hline
\end{tabular}

Source: Field survey, $2019 *$ Multiple responses Figure in parentheses represents percentage

Table 4. Mean distribution of the respondents based on Community-based Agricultural Projects participated in due to rural-urban interactions

\begin{tabular}{|c|c|c|c|c|c|}
\hline \multirow[t]{2}{*}{ Community-Based Agricultural projects } & \multirow{2}{*}{$\begin{array}{c}\text { CBPs participated in } \\
\text { due to interactions } \\
\text { Yes * }\end{array}$} & \multicolumn{3}{|c|}{ Level of participation in CBPs } & \multirow[b]{2}{*}{$\begin{array}{c}\text { Mean } \\
\operatorname{score}(\bar{x})\end{array}$} \\
\hline & & High & Moderate & Low & \\
\hline Provision of improved varieties of seeds to farmers & $58(19.3)$ & $4(6.9)$ & $46(79.3)$ & $8(13.8)$ & $0.367^{*}$ \\
\hline Provision of improved breeds of animals to farmers & $32(10.7)$ & $9(28.1)$ & $17(53.1)$ & $6(18.8)$ & $0.273 *$ \\
\hline Provision of Farm tools to farmers & $38(12.7)$ & $4(10.5)$ & $31(81.6)$ & $3(7.9)$ & $0.256^{*}$ \\
\hline $\begin{array}{l}\text { Provision of loans to farmers for buying farm } \\
\text { inputs }\end{array}$ & $44(14.7)$ & 0 & $27(61.4)$ & $17(38.6)$ & $0.236^{*}$ \\
\hline Provision. of grinders \& threshers & $11(3.7)$ & 0 & $8(72.7)$ & $3(27.3)$ & 0.060 \\
\hline Erection of silo and rhombus & $23(7.7)$ & 0 & $13(56.5)$ & $10(43.5)$ & 0.086 \\
\hline Procurement of freezer & $13(4.3)$ & $1(7.7)$ & $7(53.8)$ & $5(38.5)$ & 0.163 \\
\hline
\end{tabular}

Source: Field survey, 2019 Figure in parentheses represents percentage *Multiple responses

Grand mean $=0.205$

\section{Rural Dwellers' Level of Participation in Agricultural Projects Based on Rural-urban Interactions}

Table 4 reveals that the community-based agricultural projects provided based on rural-urban interactions were provision of improved varieties of seeds to farmers, provision of improved breeds of animals, provision of farm tools and provision of loans to farmers for buying farm inputs $(\overline{\mathrm{x}}=0.367,0.273,0.256$ and 0.236$)$ respectively. Respondents' level of participation was moderate for all the projects. The further buttresses the submission of IFAD (2015) that the interdependence between rural and urban areas is increasing rural growth (especially within food systems), underpins the sustainability of urban areas and this growth in urban sectors also provides opportunities to raise rural incomes. The implication is that rural-urban interactions if properly harnessed can stimulate agricultural development.

\section{Respondents' Perception of the Effects of Rural-urban Interactions on Their Participation in Community- Based Agricultural Projects}

Results on Table 5 show that the rural dwellers expressed favorable perception to statements such as: I now enjoy up to date information on improved agricultural technologies and community driven participation, thanks to various seminars and agricultural shows organized by the research institutes in the city $(\bar{x}=4.11)$, I enjoy selling my farm produce to those in the cities because it gives me more profit and business contact to further participate in community-based agric projects $(\overline{\mathrm{x}}=3.90)$ and the out-flow of my farm produce to the urban areas in exchange for money has enabled me to contribute meaningfully to community-based agric projects in my village $(\bar{x}=3.88)$ $(\overline{\mathrm{x}}=3.85)$. This implies that the respondents perceived rural-urban interactions as a tool for encouraging participation in agricultural development.

This implies that rural-urban interactions can stimulate rural dwellers' participation in community-based projects. 
Table 5. Distribution of the rural dwellers based on their perception on the effects of forms of rural-urban interactions on their participation in community-based agricultural projects in the study area

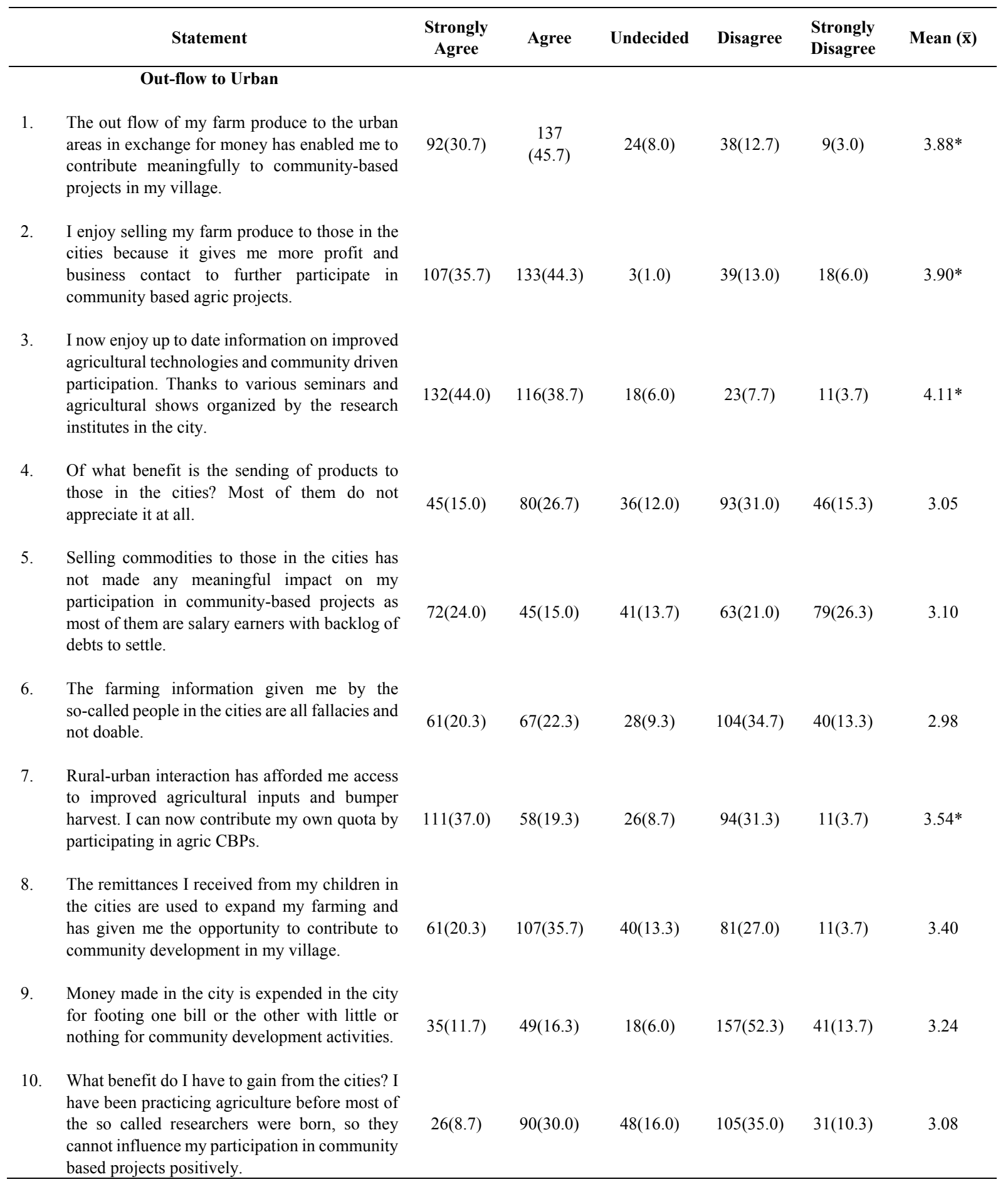

Source: Field survey, 2019 *Positive perception, Figure in parentheses represents percentage Grand mean=3.42 


\section{Hypotheses}

Relationship between the selected socio-economic characteristics of the respondents and level of participation in community based agricultural projects.

Results on Table 6 show that occupation $\left(X^{2}=36.746\right)$, educational attainment $\left(X^{2}=21.249\right)$, marital status $\left(X^{2}=11.920\right)$, and status in the household $\left(X^{2}=8.681\right)$ were found to be significant to participation in community-based agricultural projects. This suggests that being married, educational level, occupation and status in the household tend to stimulate participation in agricultural projects.

Table 6. Chi-square analysis showing significant relationship between the selected socio-economic characteristics of the respondents and participation in community -based agricultural projects

\begin{tabular}{cccc}
\hline & $\mathbf{X}^{\mathbf{2}}$ - value & df & p-value \\
\hline Agricultural projects & & & \\
Occupation & 36.764 & 8 & $0.000^{*}$ \\
Educational Attainment & 21.249 & 8 & $0.007^{*}$ \\
Marital Status & 11.920 & 3 & $0.008^{*}$ \\
Status in the household & 8.681 & 2 & $0.013^{*}$ \\
Sex & 2.910 & 1 & 0.088 \\
Religion & 0.467 & 2 & 0.792 \\
\hline
\end{tabular}

Source: Field Survey, $2019 \quad$ *Significant at $\mathrm{p}<0.05$

Relationship between the respondents' motivational factors for rural-urban interactions and their participation in the various community-based agricultural projects

Table 7 shows that rural dwellers' motivational factors for rural- urban interactions had significant influence on the respondents' participation in community-based agric projects $\left(\chi^{2}=1.595\right)$. This again corroborates IFAD (2015) that the interdependence between rural and urban areas is increasing rural growth (especially within food systems), underpins the sustainability of urban areas and this growth in urban sectors also provides opportunities to raise rural incomes.

Table 7. Relationship between the respondents' motivational factors for rural-urban interactions and their participation in community based agricultural Projects

\begin{tabular}{cccc}
\hline Variables & $\mathbf{X}^{2}$-value & df & p-value \\
\hline Agricultural projects & 1.595 & 1 & $0.000^{*}$ \\
\hline
\end{tabular}

Source: Field Survey, $2019 *$ Significant at $\mathrm{p}<0.05$

\section{Summary}

The study was carried out to examine the perceived effects of rural-urban interactions on sustainable Agricultural Development in Nigeria. The study ascertained the socio-economic characteristics of the respondents, identified the factors that motivate the respondents towards rural-urban interactions, indicated the forms of rural-urban interactions, determined the rural dwellers' level of participation in community-based agricultural projects and determined the respondents' perception of the effects of rural-urban interactions on their participation in community-based agricultural projects. The study tested two null hypotheses as:

$\mathrm{Ho}_{1}$ : there is no significant relationship between the selected socio-economic characteristics of the respondents and their participation in community-based agricultural Projects; and

$\mathrm{Ho}_{2}$ : there is no significant relationship between the respondents' motivational factors for rural-urban interactions and their participation in community-based agricultural projects.

It was observed during the study that the mean age of the respondents was 46 years while the primary occupation of the respondents was farming with the earned monthly income of between $\$ 30,000$ and $\$ 50,999$. Findings from the study also revealed that the community-based agricultural projects provided based on rural-urban interactions were provision of improved varieties of seeds to farmers, provision of improved breeds of animals, provision of farm tools and provision of improved breeds of animals to farmers $(\bar{x}=0.367,0.273,0.256$ and 0.236$)$ respectively. Also, the motivational factors for rural-urban interactions had significant effect on the respondents' participation in the community based agricultural projects $\left(X^{2}=1.595 \mathrm{p}<0.05\right)$.

\section{Conclusion}

The study submits that rural-urban interactions is significant to agricultural development as a significant relationship exists among the socio-economic characteristics, motivational factors for rural-urban interactions and the respondents' participation in community-based agricultural projects.

\section{Recommendations}

Therefore, the study recommends that:

i. spatial and sectoral rural-urban interactions should be harnessed by the stakeholders (governments, policy planners, community development experts and the rural dwellers) involved in community development projects and policy making in Nigeria to promote the standard of living in the rural areas through active participation of rural dwellers in community-based projects;

ii. local leaders, individuals, social groups and community development experts should 
re-orientate the rural dwellers on the need for mutual rural-urban interactions; and

iii. rural-urban interactions should be regulated by community development experts as a means of promoting sustainable agricultural production and development.

\section{REFERENCES}

[1] Adisa, B.O., Akinbile, L.A. and M. A. Oladoja (2004). Effects of Farmers' Characteristics and their Sources of Information on Improved Rabbit Management Practices in Osun State, Nigeria. African Journal of livestock extension, Vol.3, pp.37-44.

[2] Adeleke-Bello, O. O. and Ashimolowo, O.R. (2015). Beneficiaries' Perception of Selected Rural Women Empowerment Projects in Ogun State, Nigeria. African Journal of Agricultural Research. 10 (44): 4108-4116.

[3] Akkoyunlu, S. (2013). The Potential of Rural-urban Linkages for Sustainable Development and Trade. NCCR Trade working papers series No.37

[4] Aliakbar, T.; Mirnajaf, M. and, Hamidian, H. (2015). Analysis of Spatial Interactions of Urban and Rural Areas an Emphasis on Rural Development. Journal of Research and Rural Planning, Vol.4 (3), pp. 25-27.

[5] Aromolaran, A. K., Alarima, C. I., Abiona, B. G., Adekola, O. A. and Amole, A. B. (2018). Attitude of Rural Households to Community Development Projects in Ogun State, Nigeria.Nigerian Journal of Rural Sociology Vol. 18, No. 2, pp 69-76

[6] Bah, M., Cisse, S., Diyamett, B., Diallo, G., Lerise, F., Okali, D., Okpara, E., Olawoye, J., and Tacoli, C., (2003). Changing rural-urban linkages in Mali, Nigeria and Tanzania. Environmental and Urbanization Vol.15 No. 1, pp. $13-22$.

[7] Bryceson, D. F. (1999). De-agrarianisation and Rural Employement in Sub-Saharan Africa: A Sectoral Perspective. World Development Vol.24 (1) pp. 97-111.

[8] Enyi, J.E. (2014). Rural and Community Development in Nigeria: An Assessment. Arabian Journal of Business and Management Review (Nigerian Chapter), Vol.2, pp. 17-30.

[9] National Population Commission (2006). Nigeria Population. Summary of the Latex Population Census of Nigeria

[10] Fhika, J.R. (2015). Participation of Rural Community Members in Rural Development in Tanzania. Ph.D. Thesis, University of South Africa, pp. 108-200.

[11] IFAD (2015). Rural transformation: Key to sustainable development. JLIFAD Investing in Rural People, pp.1-7.

[12] Iliya, M.A. (1999). Income Diversification in Semi- Arid Zone of Nigeria: A Study of Gigane, Sokoto State, NorthWest Nigeria ASC Working Paper 39: Afrika Studiecentrum,
Leiden /Centre for Research and Documentation (CRD), Kano.

[13] Ladele, A.A. and Olaniyan, O.A. (2015). Perceived effectiveness of The Community Development Service of the National Youth Service Corps Scheme in Host Communities in Osun State. Annals of Child and Youths Studies, Vol. 6(1) pp. 127-143.

[14] Lindile, L.N. (2013). An Analysis of Rural-Urban Linkages and their Implications for Policies that Sustain Development in a Space continuum. pp 1-21.

[15] Mushi, S.N. (2003). Regional Development through Rural-Urban Linkages: The Dar-es Salaam Impact Region. A Thesis submitted to the Faculty of Spatial Planning, University of Dortmund, pp.1-4.

[16] Mwaura, M., \& Ngugi, K. (2014). Factors affecting performance of Community-based Organization Projects in Kisii County, Kenya. International Journal of Social Sciences Management and Entrepreneurship, Vol. 1(2) pp. $51-67$.

[17] Ogunleye-Adetona, C.I. (2013). The Role of Community Self Help Projects in Kwara State, Nigeria. International Journal of Development and Sustainability, Vol. 2 No.1, pp28-45.

[18] Okali, D. Okpara, E. and Olawoye, J. (2001). IIED Working Paper Series on Rural-Urban Interaction and Livelihood Strategies. The case of Abia and its region, South Eastern Nigeria. pp 47-54.

[19] Okunlola, J. O. And Adesida, E.I. (2015). Effects of Community Participation on the Sustainability of Rural Infrastructure in Ondo State, Nigeria. Asian Journal of Agricultural Extension, Economics and Sociology, Vol. 7(1) pp. 1-9.

[20] Olariu, C.P. (2012). Sustainable Rural Development Through Good Practice Models, Vol. xi (1)

[21] Oyesola, O.B. and Oladeji, J.O. (2006). Spatial Interaction of Rural Dwellers and Participation in Community Development Activities in Oyo State. Proceedings of the Eleventh National Conference of the Agricultural Extension Society of Nigeria pp. 63-70.

[22] Tacoli, C. (2004). Rural-Urban Linkages and Pro-Poor Agricultural Growth: An Overview. Agriculture and Pro-Poor Growth Task Team Workshop Held June 17-18, Helsinki.

[23] Tacoli, C., McGranahan G. and Satterthwaite D.(2014).World Migration Report 2015. Urbanization, Rural-urban Migration and Urban Poverty, Geneva, International Organisation for Migrations (IOM).

[24] Toyobo, A. and Muili, A. B. (2008). Constraints Militating Against Effectiveness of Community Development Projects in Ilesha. Journal of Geography and Regional Planning Vol. 3(8), pp. 144-150.

[25] Trager, L. (2000). Migration and Rural-Urban Linkages: Implications for Rural Development, Poverty Alleviation and Gender Relations. Distinguished Lecture Series No.1, Centre for Gender, Governance and Development, Ibadan. 